\title{
Understanding Growth and Malnutrition in Baka Pygmy Children
}

\author{
Stephan M. Funk ${ }^{1,2} \cdot$ Belén Palomo Guerra $^{3}$ - Amalia Bueno Zamora ${ }^{4} \cdot$ Amy Ickowitz $^{5}$ - Nicias Afoumpam Poni ${ }^{4}$. \\ Mohamadou Aminou Abdou ${ }^{6}$. Yaya Hadam Sibama ${ }^{6}$. René Penda ${ }^{6}$. Guillermo Ros Brull ${ }^{4}$. Martin Abossolo ${ }^{4}$. \\ Eva Ávila Martín ${ }^{4}$ - Robert Okale ${ }^{4}$. Blaise Ango Ze ${ }^{4}$. Ananda Moreno Carrión ${ }^{4}$. Cristina García Sebastián ${ }^{7}$. \\ Cristina Ruiz de Loizaga García ${ }^{8}$. Francisco López-Romero Salazar ${ }^{9} \cdot$ Hissein Amazia $^{4}$ - Idoia Álvarez Reyes ${ }^{10}$. \\ Rafaela Sánchez Expósito ${ }^{4}$ Julia E. Fa ${ }^{5,11}$ (D)
}

Published online: 31 May 2020

(C) The Author(s) 2020

\begin{abstract}
We determined stunting, wasting, and obesity frequencies in a total 1092 2-to-12 year old Baka Pygmy children from anthropometric and health data gathered in 34 villages in the Djoum-Mintom region in southeastern Cameroon in four health campaigns in 2010 and 2017-9. We compare these to the WHO Child Growth Standards, Amazonian Tsiname growth references for interpopulation comparisons and the study population itself. Population-specific growth charts were constructed using GAMLSS modelling. Our results show that Baka children have one of the highest global rates of stunting relative to the WHO child growth standard with $57.8 \%$ for 2-to- 12 year olds and $64 \%$ and $73 \%$ for 2-to-4 year old girls and boys, respectively. Frequencies of wasting, overweight, and low BMI were low at 3.4\%, 4.6\% and 4.3\%, respectively, for 2-to-12 year olds. Underweight was at $25.5 \%$, in the upper range for sub-Saharan Africa. Edemas indicated rare severe malnutrition $(0.3 \%)$. Uncertainties in age estimation had dramatic effects on the reliability of estimated individual z-scores but distributions of z-scores were robust at a population level. In the context of the recent evidence for genetic adaptation of the Pygmies' small stature to the tropical forest environment we argue that WHO child standards for weight and BMI are applicable. However, standards for height are clearly not adequate for Pygmy people. To achieve UN Sustainable Development Goals, we recommend that Pygmy specific growth standards are developed for the various, genetically differing Pygmy tribes.
\end{abstract}

Keywords Indigenous peoples $\cdot$ Baka $\cdot$ Health $\cdot$ WHO child growth standards $\cdot$ Central Africa $\cdot$ Cameroon

\section{Introduction}

Malnutrition remains the gravest single threat to global public health, accounting for about $45 \%$ of deaths in children

Stephan M. Funk and Belén Palomo Guerra are joint first authors.

Electronic supplementary material The online version of this article (https://doi.org/10.1007/s10745-020-00161-5) contains supplementary material, which is available to authorized users.

Julia E. Fa

jfa949@gmail.com

NaturaHeritage, Jersey, Channel Islands, UK

2 Centro de Excelencia en Medicina Traslacional, Universidad de La Frontera, Francisco Salazar, 1145 Temuco, Araucanía, Chile

3 Hospital Universitario de Móstoles, Móstoles, Madrid, Spain

4 Zerca y Lejos NGO, Madrid, Spain

5 Center for International Forestry Research, Bogor, Indonesia
$<5$ years of age (WHO 2018). Sub-Saharan Africa has one of the highest levels of child malnutrition globally (Akombi et al. 2017). In this region, child mortality in part caused by inadequate food intake is higher among indigenous and tribal
6 Faculté de Médecine et Sciences, Biomédicales, Université de Yaoundé, Yaoundé, Cameroon

7 Hospital Universitario Ramón y Cajal, Madrid, Spain

8 Hospital Universitario Severo Ochoa, Leganés, Madrid, Spain

9 Hospital Universitario 12 de Octubre, Madrid, Spain

10 Consorci Sanitari Integral de L'Hospitalet de Llobregat, Barcelona, Spain

11 Department of Natural Sciences, Manchester Metropolitan University, Manchester, UK 
peoples than in sympatric non-indigenous groups (Anderson et al. 2016). Malnutrition refers to deficiencies, excesses, or imbalances in a person's intake of energy and/or nutrients. The term malnutrition covers 'undernutrition'-which includes stunting (low height for age), wasting (low weight for height), underweight (low weight for age), micronutrient deficiencies or insufficiencies (a lack of important vitamins and minerals), and 'overnutrition,' which includes overweight and obesity. Factors affecting undernutrition are manifold, ultimately determined by socioeconomic and political factors that prolong poverty and social inequities (Pridmore and Carr-Hill 2011; Heaton et al. 2016). Growth failure leading to stunting is the most prevalent type of undernutrition worldwide (UNICEF et al. 2020). While short stature is not usually by itself a problem, stunting increases morbidity and mortality, risk of infection, and reduces and delays physical and cognitive development resulting in low adult incomes and intergenerational transmission of poverty (reviewed in Prendergast and Humphrey 2014). Overnutrition is a major cause of noncommunicable diseases such as heart disease, stroke, diabetes, and cancer.

To improve maternal, infant and young child nutrition worldwide, regional differences need to be identified (Akombi et al. 2017). Appropriate diagnostic tools, such as reference growth curves, are therefore essential to guide local, national, and international health policies. In 2006, the WHO Child Growth Standards were introduced for infants and children from birth to 5 years of age (WHO Multicentre Growth Reference Study Group 2006). These charts are based on data gathered from healthy breastfed infants and young children from widely diverse ethnic backgrounds and cultural settings (Brazil, Ghana, India, Norway, Oman, and USA). Growth curves for the 5 to 19 years age group, closely aligned with the WHO Child Growth Standards at 5 years, were developed in 2008 (Bloem 2007; de Onis et al. 2007).

WHO child growth charts are considered good models for how children should grow in all countries and for all ethnicities (WHO Multicentre Growth Reference Study Group 2006; Bloem 2007; de Onis et al. 2007; de Onis 2008). These charts follow a "biomedical approach" when interpreting growth perturbations and small size (Schell and Magnus 2007). This infers that small size is essentially a sign of poor health, inadequate nutrition, negative energy balance, or negative psychosocial environment rather than a genetic, physiological or ontogenic adaptation to environmental conditions (Schell and Magnus 2007).

Deviations from WHO standards have been reported in a number of national studies. For example, weights of Canadian children differed significantly between mothers of European ancestry and mothers of Asian/Pacific or South Asian heritage regardless of feeding practice (Park et al. 2017). Though not fully understood, such dissimilarities are likely to be associated to genetic differences within and between populations. Twin studies indicate that about $80 \%$ of the variance in height is explained by genetic factors (Jelenkovic et al. 2016) but genetics only accounted for about $25 \%$ of the observed variance in a study of European populations involving over 250,000 individuals, 17,500 sibling pairs (Robinson et al. 2015).

There is broad consensus for the absence of major genetic differences in the average growth potential among human populations (Stinson 2012; Natale and Rajagopalan 2014; NCD Risk Factor Collaboration (NCD-RisC) 2016). Conversely, environmental and socioeconomic factors affect growth as demonstrated by the widespread upturns in adult height in affluent countries and more recently in developing countries, the socalled secular trends, as living conditions have improved over the last century (NCD Risk Factor Collaboration (NCD-RisC) 2016). A meta-analysis of over 11 million children aged $<5$ years from 55 countries and ethnic groups showed that the study means for height were generally within $\pm 0.5 \mathrm{SD}$ of the means in WHO growth standards, except for taller European populations and smaller populations in Saudi Arabia and Asian Indians (Natale and Rajagopalan 2014). Despite these exceptions, the WHO and others (e.g., a recent editorial discussing the observed differences of the above cited study on Canadian children (Park et al. 2017)), state that WHO standards are adequate and "suitable for everyone" (Ong 2017) and that "country- or race-specific growth references are not advised" (de Onis 2008). Since 2011, except for a few countries, the WHO growth standards have been adopted worldwide (WHO Multicentre Growth Reference Study Group 2006; de Onis et al. 2012).

Data on childhood growth and measurement of malnutrition levels are lacking for geographically restricted rainforest hunter-gatherers in South America and Africa (Stinson 2012; Natale and Rajagopalan 2014). These groups exhibit large variations in stature but have characteristically small body size (Stinson 1990, 2012; Natale and Rajagopalan 2014; Urlacher et al. 2016; Olivero et al. 2016; Blackwell et al. 2017). A study of children of the Shuar of Ecuador and the Tsiname of Bolivia (Urlacher et al. 2016; Blackwell et al. 2017; Martin et al. 2019) found that using WHO standards stunting rates were $40 \%$, corresponding to about the median stunting rates in indigenous Amazonians (Foster et al. 2005). For Amazonians in general, high rates of child stunting but low rates of underweight (low weight for age) and wasting are typical, suggesting the effect of shared environmental challenges such as high heat, humidity, and pathogen density, and low food availability (Blackwell et al. 2017; Perry and Verdu 2017). However, despite the fact that genetic adaptation to tropical forest habitats has been extensively considered (Schell and Magnus 2007; Urlacher et al. 2016), nutritional insufficiency and infectious disease are generally suggested as being the main causes of small stature (Stinson 1990, 2012; Orr et al. 2001; Foster et al. 
2005). In the Tsimane study (Martin et al. 2019), the authors suggest that WHO growth standards "remain ideal for between-population comparisons and assessment of largescale health interventions" but should be used in combination with a population-specific growth reference (Blackwell et al. 2017).

The characteristic average short stature of African Pygmies ${ }^{1}$ native to the Congo Basin, is well documented. Some authors suggest that these groups would not fit the WHO growth standards, requiring population-specific references or standards (Natale and Rajagopalan 2014). However, growth studies of Pygmies are lacking due to the small and scattered nature of their populations (Olivero et al. 2016) as well as being complicated by issues such as inaccurate age estimation (Diekmann et al. 2017). Only one study has measured growth patterns in a Southeastern Cameroonian Baka Pygmy population in detail (Rozzi et al. 2015), describing mean height-for-age $z$-scores that vary around -3 and mean weight-for-age $z$-scores that fluctuate around -2 from the age of 2 years to adulthood. How these results compare to Amazonian or other indigenous populations is unclear as these z-scores are based on French growth references rather than WHO standards (Rozzi et al. 2015).

Unlike Amazonians, the short stature of African Pygmies is known to have a substantial degree of genetic foundation (Perry and Dominy 2009; Becker et al. 2011; Jarvis et al. 2012; Perry et al. 2014; Pemberton et al. 2018). Recent genomic studies have shown positive selection for loci linked to the Pygmy phenotype (Jarvis et al. 2012; Lachance et al. 2012;

\footnotetext{
${ }^{1}$ Although numerous alternative terms to Pygmy have been used to refer the rainforest hunter-gatherers of the Congo Basin, none have been agreed upon by academics or the people themselves to replace it. Although some academics and Central African government officers feel the term Pygmy is derogatory or does not adequately represent the people, the term Pygmy sensu lato, to refer to all hunter-gatherer groups in Central Africa, is widely used by a broad group of people in Europe, Japan, the United States and Africa. Moreover, International and local NGOs use the term in their titles or literature, e.g., Pygmy Survival Alliance, Forest Peoples' Programme, Survival International, Rainforest Foundation, Reseau Recherches Actions Concerteees Pygmees, Centre d'Accompagnement des Autochtones Pygmees et Minoritaires Vulnerables, and the Association for the Development of Pygmy Peoples of Gabon. Congo Basin conservation groups, such as World Wildlife Fund and Wildlife Conservation Society and international human rights groups working in the region, such as UNICEF and Integrated Regional Informaton Networks (IRIN), also regularly use the term Pygmy in their literature.

We consider all groups under the umbrella of Pygmy as expressing an equivalent spatial relationship between their presence and their immediate environment. In so doing, we do not ignore the fact that various 'Pygmy' groups express distinct cultures and in some case ethnicity from other 'Pygmy' groups, and our use of the term is not meant in any way a disrespect to the various ethnicities. Although it is likely that there may be cultural reasons for geographical location and distribution, we argue that the ecological setting is a primary driver in humans in choosing localities to live in. Ichikawa (2014)14:332-3 - 'The forest plants and animals provide the people with the basis for their cultural identity. Their life and culture cannot be maintained without the forest in its entirety ... The destruction of the forest would result in the deterioration of a culture that is heavily dependent on, and in very significant ways a part of, the Congo Basin rainforest.'
}

Migliano et al. 2013; Amorim et al. 2015; Hsieh et al. 2016), highlighting the importance of revisiting the interpretation of small size for hunter-gatherers in tropical forests.

In this study, we use anthropometric and health data to estimate stunting, wasting, and obesity frequencies for a large sample of Baka Pygmy children living in southeastern Cameroon. We expand on the previous study (Rozzi et al. 2015) by using the WHO Child Growth Standards to contrast our results with published Amazonian Tsiname WHO Child Growth Standard-referenced growth curves for interpopulation comparisons. We also develop a reference growth curve for the studied Baka population for future population monitoring. We selected Baka as a representative of a Western Pygmy group as part of a long-term project providing heath and development support. Our analysis is important as the Baka suffer from poorer health than sympatric peoples because of greater poverty and insufficient health care (Anderson et al. 2016; The Lancet 2016). As a consequence of these inequalities and typically prevalent infections of tropical forest hunter-gatherers (Gurven et al. 2007) the average life expectancy at birth of the Baka is 35 years of age compared to neighboring Bantu populations who live about 22 years longer (Anderson et al. 2016).

\section{Methods}

\section{Study Area and Data Collection}

We monitored Baka children and adults during mobile clinics in villages in the Dja et Lobo Department, southeastern Cameroon. All study villages were located along the Olounou-Djoum-Mintom road (Fig. 1).

The region is covered by tropical broadleaf humid forests of the North-Western Congolian lowland forests ecoregion (Dinerstein et al. 2017). A large proportion of these forests are relatively intact primary vegetation just south of the Dja Faunal Reserve, one of the most important conservation areas in Cameroon and in Central Africa.

Although the Baka in this region lived a nomadic lifestyle as hunter-gatherers, during the last 50 years some groups have been sedenterized in roadside small townships and hamlets (Fig. 1). Village Baka survive from hunting-gathering activities (wild meat and plants) from the surrounding forests and, to a lesser extent, from growing subsistence crops. Most people in the region are poor, but poverty levels are especially severe amongst the Baka.

Clinics were run by a team of qualified medics (BPG, AMC, CGS, CRLG, FLRS, HA, IAR, RSE), under the auspices of Zerca y Lejos (ZyL). ZyL is a Spanish NGO that has been active in all our study villages providing health and development support since 2002 (Zerca y Lejos 2018). 


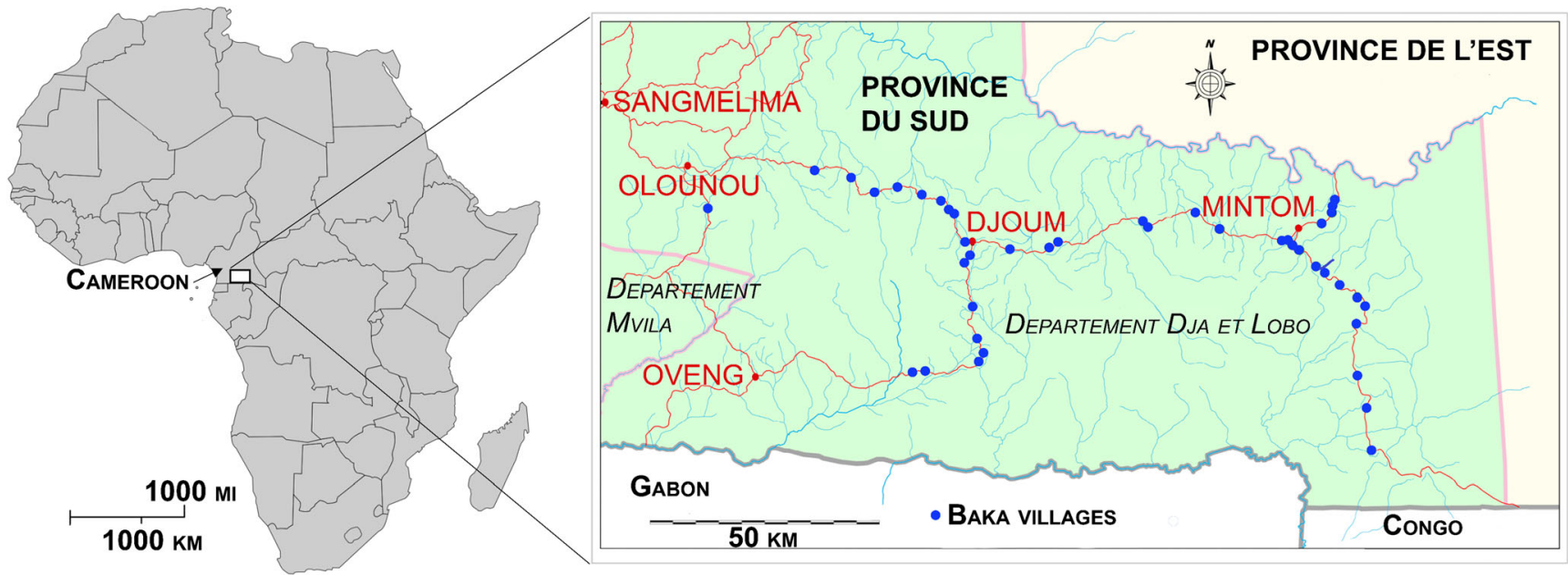

Fig. 1 Map of the study area in Southeast Cameroon. Mapped are main towns (labelled) and the smaller Baka villages and hamlets (blue dots)

Out of a total of 42 villages found in the study area (Fig. 1), ranging in size from 25 to about 120 inhabitants, we visited 34 of these in four campaigns (all undertaken in February/March each year) in 2010, 2017, 2018 and 2019. We sampled 21 villages in 2010 and 2017, 10 in 2018 and 11 in 2019; 18 villages were visited once, 7 twice, 5 three times, and 4 four times. The 2018 and 2019 clinics focused on the same 10 villages. In 2018, we mapped all houses in these 10 villages and identified the number of families and persons per family per village. By comparing these population census data with the number of people attending clinics, we estimated the representativeness of sample sizes for 2018. The 2010 and 2017-9 campaigns were independent from each other, but some persons were examined more than once during the 2017-9 period.

Clinics were open to all villagers, who were encouraged to attend even if they were not unwell. All attendees were given a routine physical examination to check overall health and were offered medications as required. For each person, we recorded their village of residence, ethnicity (self-declared; Baka and Bantu), name, sex, age (in months or years), weight $(\mathrm{kg})$, and height $(\mathrm{cm})$, clinical data on hemoglobin levels, $\mathrm{Hg}$ (in $\mathrm{g} \mathrm{l}^{-1}$ ) and absence/presence of edema. Since official documentation of identity and age was generally not available, we estimated age in three-month intervals for babies up to 2 years old and in years for all others. Mothers were asked for the age of their children in years, since exact ages in months was not always possible. We also crosschecked age estimations by dental eruption, but this method only allows categorization in years.

Anthropometric measurements were taken according to international recommendations. Infant length was measured using a mobile Seca 210 (graduation $5 \mathrm{~mm}$ ) pediatric measuring mat (Lohman et al. 1988). Child and adult standing heights were measured barefoot to the nearest $0.1 \mathrm{~cm}$ using a portable Seca ${ }^{\circledR} 213$ stadiometer. Infant and child weights up to $25 \mathrm{~kg}$ was measured with a suspended dial balance (Kerbl®) to the nearest $0.1 \mathrm{~kg}$. The scale was hung from a wooden beam in one of the participants' home. Child and adult weights above $25 \mathrm{~kg}$ were measured to the nearest $0.1 \mathrm{~kg}$ with a digital scale $($ Accuweight $(\AA)$ placed on an asphalt surface to ensure no distortion. All measurements were taken with the participants dressed in light clothing. Finger-prick blood samples were obtained with a lancet after locally applying an antiseptic solution. The first blood drop was discarded. Hemoglobin level was measured to the nearest $0.1 \mathrm{~g} / \mathrm{dL}$ using a portable system (HemoCue ${ }^{\circledR} \mathrm{Hb} 201+$ ) previously calibrated following indications from the manufacturer. To avoid measurement biases, we used the same equipment throughout the study and calibrated the balances every year. All measurements were taken by the same staff conducting the measurements each year.

\section{Statistical Analyses}

The observed anthropometric measures HA, WA, WH and BA were modelled using Generalized Additive Models for Location Shape and Scale (GAMLSS) (Rigby and Stasinopoulos 2005) using the R-package 'gamlss' 4.3.3 (http://www.gamlss.org/) (Stasinopoulos and Rigby 2007) in R (R Foundation for Statistical Computing 2016). GAMLSS was employed to create the WHO childhood growth standards (de Onis et al. 2007) and the R-package replicated the WHO modelling procedure as close as possible albeit modelling ages of 0 to 29 in one approach (Urlacher et al. 2016) rather than WHO's modelling of the two age groups $0-5$ years and 519 years old separately. Modelling first fits a 4-parameter Box-Cox power exponential (BCPE) distribution and then applies Generalized Akaike information criterion (GAIC) to estimate the appropriate smoothing degrees of freedom. We used the software's default parameters for initial BCPE fitting except for $\operatorname{df}(\mu)=4$ instead of $\operatorname{df}(\mu)=14$ to account for the smaller sample size compared for the sample size for which gamlss was developed (Urlacher et al. 2016). The final GAMLSS 
parameters were then used to calculate centile tables and zscores for all individuals referenced to the sampling population itself. Range and mean \pm SD difference between observed and simulated z-scores across all individuals and 100 simulations was used to assess the effects of uncertainty in age measurements on the estimation of z-scores. Each simulation randomly assigned ages within each yearly birth cohort, followed by growth modelling and calculation of z-scores.

Multiple regression analysis and ANOVA were performed for the calculated z-scores as dependent variables and sampling period (2010, 2017-2019), anemia and absence/ presence of edema as independent variables.

We calculated z-scores with reference to the WHO growth standards and to the growth reference for the Tsimane people applying the R package 'localgrowth' (https://github.com/ adblackwell/localgrowth) (Blackwell et al. 2017). Skewness of the sample was statistically tested by a test for normality as implemented in the R package "normtest" (Gavrilov and Pusev 2015) with 10,000 Monte Carlo Simulations. Cut-off criteria for z-scores for the identification of malnutrition in individuals were two standard deviations $( \pm 2 \mathrm{SD})$ from the median of the reference population for stunting (zHA $\leq-2$ $\mathrm{SD})$, wasting (zWH $\leq-2 \mathrm{SD})$, underweight $(\mathrm{zWA} \leq-2 \mathrm{SD})$, and overweight (zWA $\geq+2$ SD) (World Health Organization 1995). Cut-off criteria for severe cases of these types of malnutrition were three standard deviations $( \pm 3 \mathrm{SD})$.

Data are publicly available (Table $\mathrm{S} 1$ ).

\section{Results}

We weighed and measured a total of 1917 persons of different ages and ethnicities (551 in 2010, 515 in 2017, 553 in 2018 and 298 in 2019). The majority of participants were Baka ( $n=$ 1651 persons), 260 were Bantu, three from other ethnicities and three undeclared. We examined a total of 191 persons in more than one campaign. The analysis of growth characteristics presented here focusses on anthropometric data for 1092 2-to-12 year old Baka children, which constitute the majority of participants seen during all clinics (Table 1). A total of 117 of these were seen in two different years, but only the first year was analyzed to avoid statistical biases.

Whilst in 2010 and 2017 we covered as many villages as possible ( 34 of the 42 villages in the region) we focused on 10 core villages in 2018 and 2019 as part of a larger ongoing project (Darwin Initiative n.d.). In total, $75 \%$ of the persons reported to live in these 10 villages were sampled in 2018 (Table 2). In some villages, more persons were sampled than residents, indicating that people from other villages also attended the clinics. The 270 children aged 2-12 included in this study correspond to approximately half of the number of inhabitants, indicating a bias towards children.

We also included 95 Baka babies up to 2 years old, as well as 156 persons aged between 12 and 29 years (Table 1) to avoid edge effects of the fitted growth models for 2-12 year olds by anchoring growth curves (Indrayan 2014) (Table 3; Fig. 2). With the exception of WH above $140 \mathrm{~cm}$, the growth curves of boys and girls matched each other well. For all anthropometrics, the percentages of individuals with z-scores $\leq-2$ approximated $2.3 \%$, the theoretical expectation assuming normal distribution (HA: $2.38 \%$, WA: $2.20 \%$, WH: $2.75 \%$, BMI: $2.66 \%$ ). The distribution of HA z-scores was not skewed $(\mathrm{T}=0.12, p=$ 0.11 , mode $=-0.25$, mean $=-0.02$ ) but small skews were observed for WA $(\mathrm{T}=0.32, p<0.001$, mode $=-0.6$, mean $=$ $0.02)$, WH $(\mathrm{T}=-0.56, \mathrm{p}=<0.001$, mode $=0.09$, mean $=0.16)$ and BMI $(\mathrm{T}=0.18, p=0.017$, mode $=-0.10$, mean $=0.03)$.

The assessment of the effects of the uncertainty in age classification by simulations indicates that observed and simulated z-scores were on average very similar but variances were large (HA: mean $\pm \mathrm{SD}=0.002 \pm 0.26$, range: $-2.2-1.2$; WA: $0.008 \pm 0.8,-3.8-2.5$; BA: $0.005 \pm 1.56,-7.3-9.1$ ).

No impact of sampling period on z-scores was observed for $\mathrm{HA}(\mathrm{F}=0.28, \mathrm{df}=1083, p=0.60)$ and WA $(\mathrm{F}=2.51, \mathrm{df}=$ $1083, p=0.11$ ), but the linear regression was significant for $\mathrm{WH}(\mathrm{F}=7.25, \mathrm{df}=1083, p=0.007)$ and $\mathrm{BMI}(\mathrm{F}=10.4, \mathrm{df}=$ 1083, $p=0.001$ ) (Fig. 3). Hemoglobin concentrations were

Table 1 Number of observations (left) and individuals sampled (right)

\begin{tabular}{|c|c|c|c|c|c|}
\hline year & gender & $0-1$ year & $2-12$ years & 13-29 years & $\sum$ \\
\hline \multirow[t]{3}{*}{2010} & $\hat{0}$ & $32 / 32$ & $240 / 240$ & $0 / 0$ & $272 / 272$ \\
\hline & q & $37 / 37$ & $220 / 220$ & $0 / 0$ & $257 / 257$ \\
\hline & $\sum$ & $69 / 69$ & 460 / 460 & $0 / 0$ & $529 / 529$ \\
\hline \multirow[t]{3}{*}{ 2017-9 } & $\hat{0}$ & $10 / 19$ & $405 / 340$ & $63 / 53$ & 478 / 403 \\
\hline & q & $17 / 16$ & 344 / 292 & 124 / 203 & 485 / 411 \\
\hline & $\Sigma$ & $27 / 26$ & 749 / 632 & $187 / 156$ & $963 / 814$ \\
\hline \multirow[t]{3}{*}{ total } & $\hat{0}$ & $42 / 42$ & $645 / 580$ & $63 / 53$ & $750 / 675$ \\
\hline & q & $54 / 53$ & $564 / 512$ & $124 / 103$ & $742 / 668$ \\
\hline & $\Sigma$ & $96 / 95$ & 1209 / 1092 & $187 / 156$ & $1492 / 1343$ \\
\hline
\end{tabular}


Table 2 Characteristics of the ten core villages sampled in 2018.

The numbers of houses, families and persons were determined by visits to all houses in the villages and interviews with the household elders

\begin{tabular}{llllllll}
\hline $\begin{array}{l}\text { Village } \\
\text { houses }\end{array}$ & $\begin{array}{l}\# \\
\text { families }\end{array}$ & $\begin{array}{l}\# \\
\text { persons }\end{array}$ & $\begin{array}{l}\text { \# persons } \\
\text { sampled }\end{array}$ & $\begin{array}{l}\text { \% of } \\
\text { total }\end{array}$ & $\begin{array}{l}2 \text { to } 12 \text { year olds } \\
\text { sampled }\end{array}$ & $\begin{array}{l}\% \text { of } \\
\text { total }\end{array}$ \\
\hline 1 & 19 & 5 & 54 & 37 & 68.5 & 19 & 51.4 \\
2 & 35 & 8 & 111 & 66 & 59.5 & 33 & 50.0 \\
3 & 28 & 6 & 106 & 54 & 50.9 & 25 & 46.3 \\
4 & 34 & 8 & 76 & 70 & 92.1 & 27 & 38.6 \\
5 & 10 & 3 & 41 & 44 & 107.3 & 19 & 43.2 \\
6 & 19 & 8 & 62 & 74 & 119.4 & 34 & 45.9 \\
7 & 29 & 6 & 109 & 52 & 47.7 & 38 & 73.1 \\
8 & 6 & 2 & 25 & 26 & 104.0 & 20 & 76.9 \\
9 & 13 & 4 & 59 & 66 & 111.9 & 24 & 36.4 \\
10 & 29 & 3 & 93 & 64 & 68.8 & 31 & 48.4 \\
$\sum$ & 222 & 53 & 736 & 553 & 75.1 & 270 & 48.8 \\
\hline
\end{tabular}

The number of persons sampled excludes incidences where persons visited the clinics repeatedly recorded in 296 children and these ranged between 5.4 and 15.2 (mean $\pm \mathrm{SD}=9.88 \pm 1.65$ ). The regression between $\mathrm{Hg}$ and z-scores was not significant for any of the anthropometrics $(\mathrm{HA}: \mathrm{F}=2.27, \mathrm{df}=294, p=0.133$; WA: $\mathrm{F}=2.79, \mathrm{df}=$ 294, $\mathrm{p}=0.1 ; \mathrm{WH}: \mathrm{F}=0.30, \mathrm{df}=294, p=0.58$; BMI: $\mathrm{F}=$ $1.13, \mathrm{df}=294, p=0.29$ ). Presence/absence of edema was checked for 627 children; only two positive cases $(0.3 \%)$ were recorded.

WHO and Tsimane-derived z-scores across all Baka individuals were highly correlated with the z-scores calculated using the Baka population itself for HA (rWHO vs Baka = 0.96, rTsiname vs Baka $=0.97$ ), WA (rWHO vs Baka $=0.97$, rTsiname vs Baka $=0.98)$ and $\mathrm{WH}(\mathrm{rWHO}$ vs Baka $=0.97$, rTsiname vs Baka $=0.96$ ), but less so for BA (rWHO vs Baka $=-0.03$, rTsiname vs Baka $=0.75$ ) (Fig.4). The distributions of z-scores for $\mathrm{WH}$ and $\mathrm{BA}$ of Baka individuals are very similar between the two scenarios of basing the $\mathrm{z}$ calculations on WHO standards, the Tsimane reference population or the Baka population itself. The Baka-derived $\mathrm{WH}$ and BA density distributions and means lie between the WHO and the

Table 3 Generalized Akaike information criterion best-fit smoothing parameters of the Box-Cox Power Exponential distributions for the GAMLSS models

\begin{tabular}{|c|c|c|c|c|c|}
\hline & gender & Age power transformation & $\operatorname{df}(\mu)$ & $\mathrm{df}(\sigma)$ & $\mathrm{df}(v)$ \\
\hline \multirow[t]{2}{*}{ Height } & $\hat{\sigma}$ & 1.0 & 5 & 3 & 1 \\
\hline & o & 1.0 & 4 & 1 & 1 \\
\hline \multirow[t]{2}{*}{ Weight } & $\hat{0}$ & 1.0 & 5 & 1 & 1 \\
\hline & q & 0.95 & 9 & 2 & 0 \\
\hline \multirow[t]{2}{*}{ BMI } & $\hat{\sigma}$ & 0.45 & 5 & 1 & 1 \\
\hline & 우 & 0.95 & 10 & 2 & 1 \\
\hline \multirow[t]{2}{*}{ WFH } & $\hat{\sigma}$ & 1.3 & 5 & 3 & 1 \\
\hline & 우 & 1.0 & 14 & 2 & 1 \\
\hline
\end{tabular}

Tsimane means. The largest discrepancy is observed for HA and the second largest for WA. In both cases, WHO-derived zscores show large shifts to negative values. The most extreme prevalence of malnutrition, defined relative to the WHO child growth standard, was observed for stunting at $57.8 \%$ followed by wasting at $25.5 \%$ and less than $5 \%$ for underweight, obesity and low BMI (Table 4). Stunting and wasting were lower at approximately $10 \%$ each, when estimated against the Tsiname reference population whilst underweight, overweight and low BMI were between 5\% and 7\%. The simulation experiments showed that the effects of uncertainty in age estimation had only little impact on the prevalence of malnutrition (Table 4). When the percentages of WHO-derived z-scores that are $\leq-2$ between Baka and Tsimane for the age classes 2 to 5 years and 5 to 10 years are compared, the percentages are consistently larger for Baka than for Tsimane for all parameters and age classes (Table 5).

\section{Discussion}

\section{Methodological Limitations}

Reliable age estimations are important for clinicians for assessing child growth and for research in evolutionary anthropology. However, many hunter-gatherer societies do not record age, and the absence of official birth records makes age estimation problematic (Hill and Hurtado 2017; Diekmann et al. 2017). Baka mothers visiting our clinics were in general certain about the age of their children in terms of years but were uncertain in terms of months and birth date. Recently, a Bayesian approach was proposed for the accurate age estimation requiring prior population information and the ranking of individuals by age obtained from interviewing members of the population (Diekmann et al. 2017). This avenue was not 
Fig. 2 Height per age (top) and weight per height (bottom) in Baka Pygmy children aged 2 to 12 years
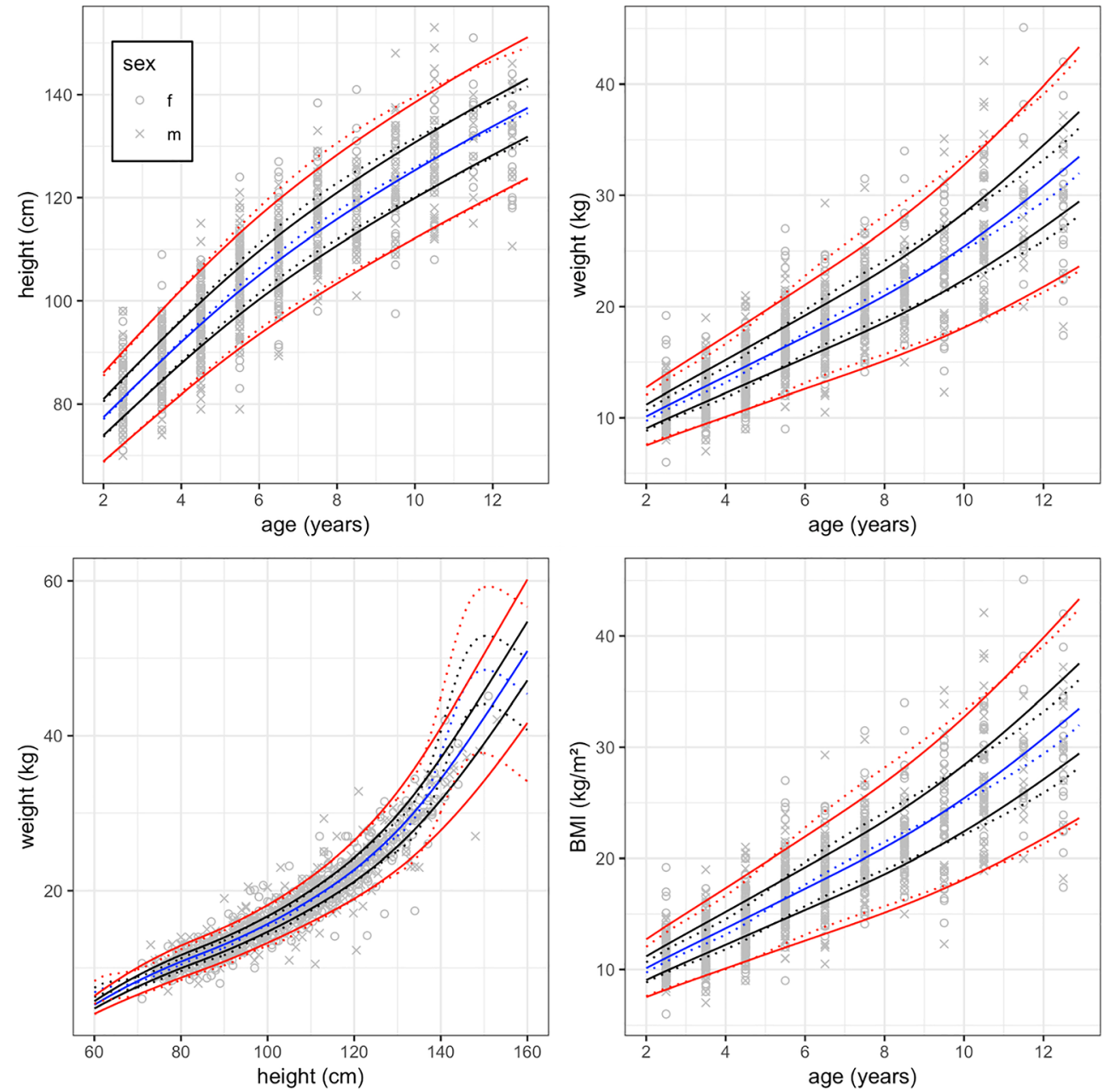

suitable for our study because a reliable ranking in a clinical setting over several years is not feasible. Moreover, stature and weight, the same parameters which we were analyzing, might bias our age estimate and thus the prior ranking. Therefore, we used Monte Carlo simulations to assess the impact of age uncertainty on the calculated z-scores of individuals and the population. For individuals, the ranges of possible differences between observed and simulated z-scores was very high, indicating that the estimators for malnutrition can be completely wrong in some cases. This highlights the need for additional longitudinal studies for the construction of reliable reference growth curves similar to the Tsimane and the Shuar (Urlacher et al. 2016; Blackwell et al. 2017). At a population level, the results were, however, robust. The simulations indicate the ranges for the percentages of stunted and wasted children was only between $2 \%$ and $3 \%$ and less than $1 \%$ for BMI.

An unbiased estimation of growth parameters for the purpose of acting as growth references and for assessing population health requires representative sampling. The sample coverage of our study villages was high both in terms of the number of villages sampled (34 out of the 42 in the region) and the percentage of the population samples in our 10 core villages. Our study is also robust in that we focused on general health screening of children and adults and did not concentrate on malnourished or sick individuals but specifically encouraged everybody to attend by involving the consent and support of the village heads, which is a widespread approach in similar studies (Ramírez Rozzi et al. 2015). Although field studies like ours cannot exclude sampling biases, the very small observed skews in the Baka growth distributions indicate that the sample is not biased towards malnourished individuals. Thus, sampling strategy and data both support a reasonable representativeness of the study population to evaluate the adequacy of the WHO standards for Pygmy populations.

\section{Baka Growth Curves}

The low WHO-referenced z-scores for height-for-age of 212 year old Baka corresponds well with the low standing height of Pygmy populations. Male mean standing height is $150.6 \pm 6.7 \mathrm{~cm}$ across 23 Central African populations with the Twa from western DRC being the shortest (mean $142 \mathrm{~cm}$ ) and the Efe from eastern DRC being the tallest (mean $161 \mathrm{~cm}$ ). In our study, the same magnitude of z-scores as the previously 
Fig. 3 Z-scores for yearly cohorts between age 2 and 12 for boys (x) and girls (o). Data were collected in 2010 (blue) and in 2017 to 2019 (red)
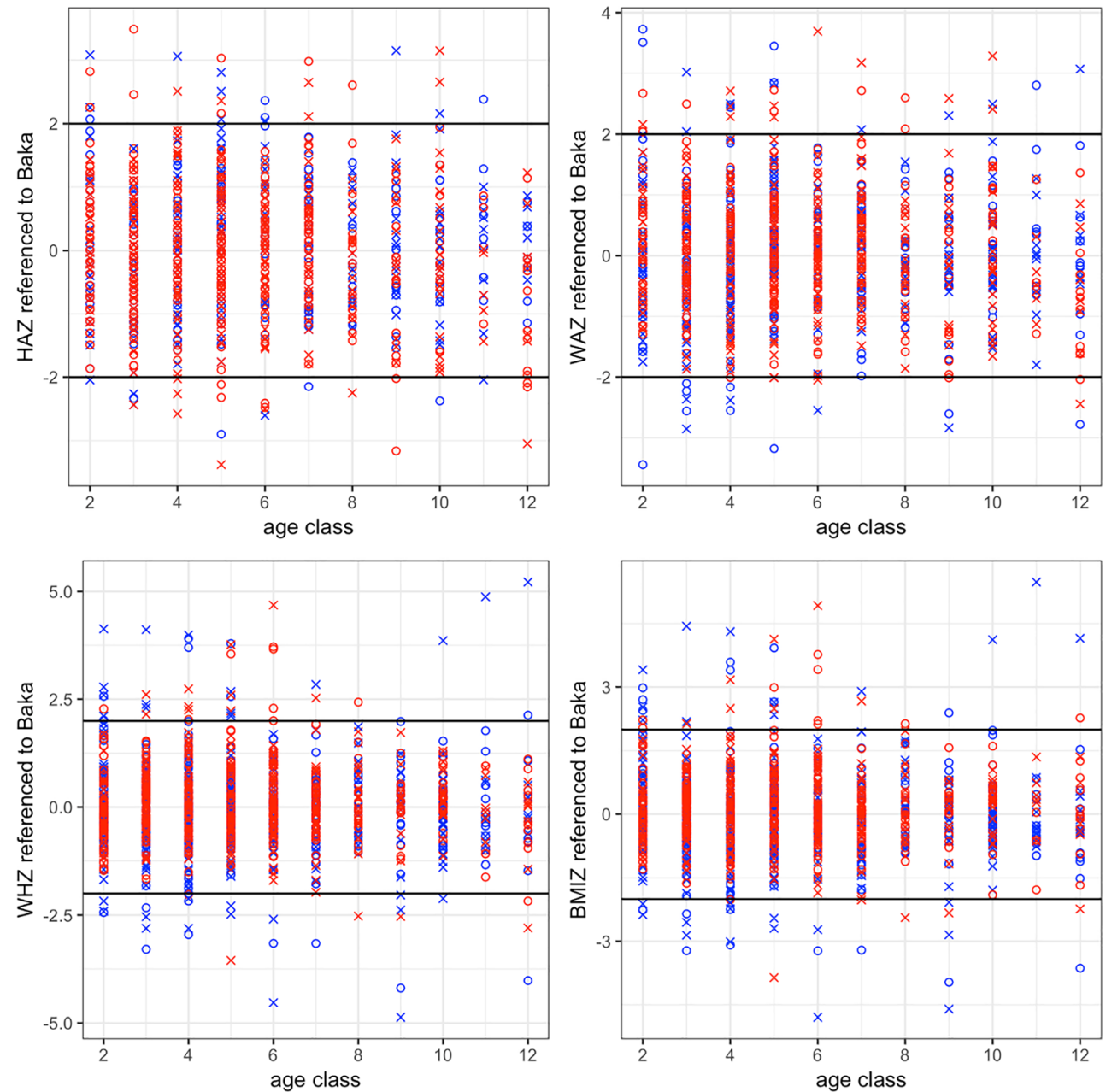

published Baka data (Ramírez Rozzi et al. 2015) was observed albeit they appear slightly smaller for weight (girls: $-1.5 \pm 0.1$, boys: $-1.6 \pm 0.2$ ) and height (girls: $-2.5 \pm 0.2$, boys: $-2.9 \pm 0.3$ ). In contrast to the previous study (Ramírez Rozzi et al. 2015), but similar to the Amazonian Tsimane and Shuar (Urlacher et al. 2016; Blackwell et al. 2017), there was a pronounced decline of mean $\mathrm{z}$-cores $\leq-2$ for both weight and height in our study for the age class five-to-ten (Table 4). The possible reasons for these discrepancies include secular trends (the previous Baka study included data from the 1990s (Ramírez Rozzi et al. 2015)) and differences between the French (Sempé and Sempé 1971) and WHO growth curves, which are not directly quantitatively comparable. That secular trends are involved is supported by the differences observed for the higher weight-for-height and BMI-for-age values between our more recent and the older sampling periods; no increase was observed for height-for-age and weight-for-age.

\section{Baka Health}

Baka growth diverges substantially from WHO values in height-for-age but is similar for BMI-for-age and weight-for- height. Weight-for-age is intermediate as expected since this parameter is impacted by both height-for-age and weight-forheight. The stunting rate of $64 \%$ and $73 \%$ for 2 -to- 4 year old girls and boys, respectively, is astonishingly high compared to anywhere in the world, including sub-Saharan Africa, where the rate was highest in Burundi, Eastern Africa with $57.7 \%$ (Akombi et al. 2017). The Baka stunting rates are approximately twice as high compared to the rate of $32.5 \%$ reported from the most recent Demographic and Health Survey (DHS) for mainly non-Pygmy people from Cameroon, and to the average of $28.8 \%$ (95\% CI: 21.4-36.2) for Central African countries (Akombi et al. 2017). Baka stunting exceeds the rates observed in Tsimane and Shuar for both sexes and for the two studied age classes 2-to-4 and 5-to-10 year olds, respectively (Urlacher et al. 2016; Blackwell et al. 2017). Wasting, however, is within the same range reported for Cameroon (5.6\%) and Central African countries $(6.7 \%, 95 \%$ CI: 4.2-9.2); the highest level of $18 \%$ was reported for Niger (Akombi et al. 2017). Children aged 0-5 years from the ethnically diverse Bantu cluster in Cameroon exhibited $45.8 \%$, $30.2 \%$ and $11.3 \%$ stunting, underweight and wasting, respectively (Nagahori et al. 2017). 
Fig. 4 Density plots of Baka-, Tsimane- and WHO-derived zscores for HA (top left), WA (top right), $\mathrm{WH}$ (bottom left) and $\mathrm{BA}$ (bottom right)
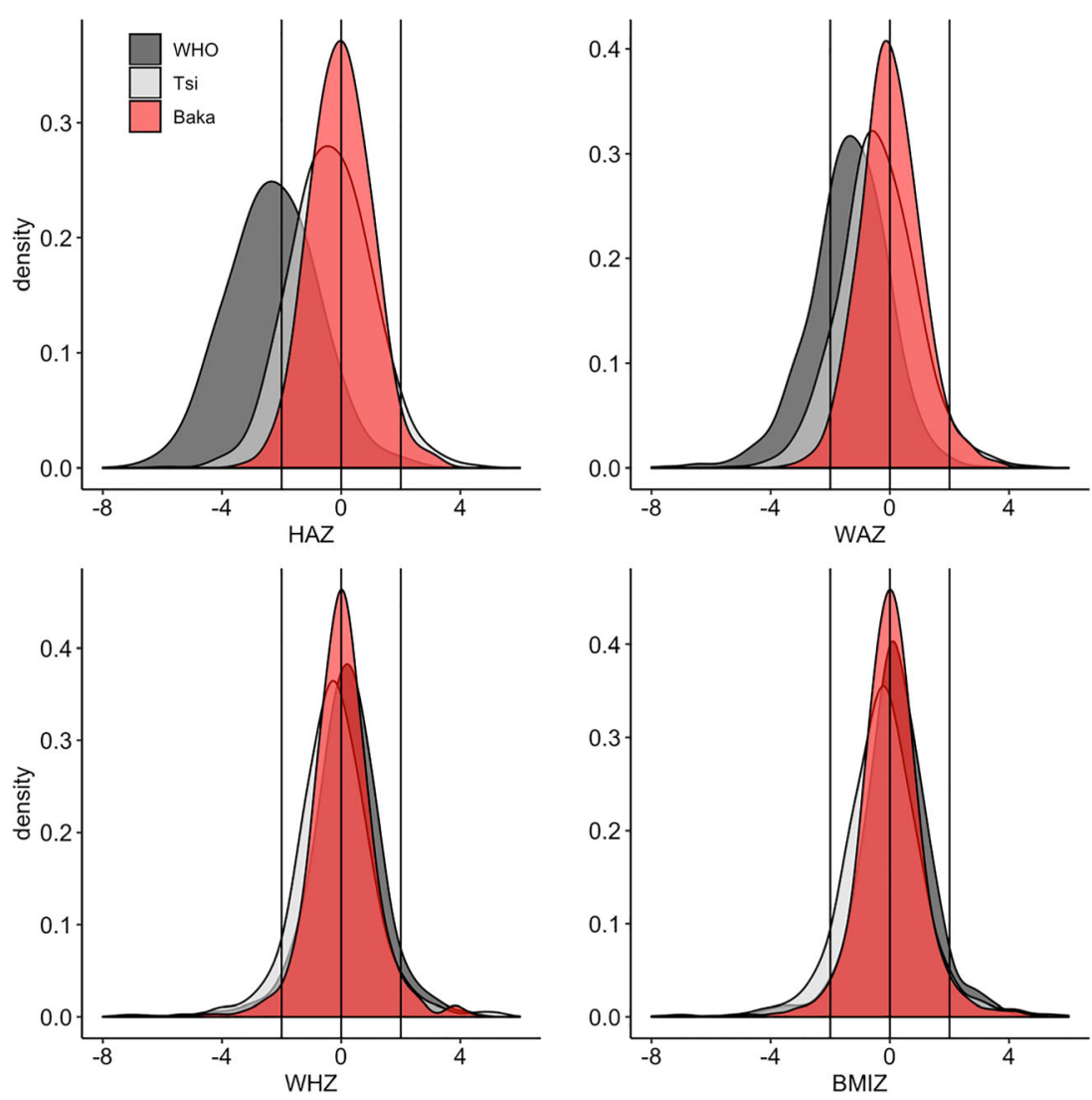

\section{Environment Versus Genetics}

However strong the link between high stunting rates and the health gap in Baka, it does not explain how much of the stunting rate is caused by health and environment. Pygmy stature is well differentiated from their non-Pygmy neighboring populations. Adult Pygmies across 23 Central-African populations have consistently smaller mean \pm SD body size $(150.6 \pm 6.7 \mathrm{~cm})$ than non-Pygmy populations $(167.3 \pm$ $5.7 \mathrm{~cm}, n=152$ sub-Saharan populations) (Froment 1993). In contrast to their non-Pygmy farming neighbors, nonsedentarised Pygmy populations live mainly as hunter- gatherers within the Congo Basin tropical rainforests (Froment 1993; Hewlett 2014). These warm and moist environmental conditions, and in particular high levels of pathogen exposure, have been suggested as causing adaptive processes in Pygmy people in Africa (Perry and Dominy 2009; Perry et al. 2014) as in indigenous Amazonians with a similar lifestyle in South America (Urlacher et al. 2016). The similarity in growth curves of the Baka, Shuar, and Tsimane suggests a population genetic and phenotypic plasticity based on shared environmental conditions, though the Baka have even higher stunting rates. However, whilst it remains unknown whether and to what extent Amazonian growth patterns have a genetic
Table 4 Summary of malnutrition in Baka children aged 2 to 12 years. The parameters wasting, stunting, underweight, obesity and low $\mathrm{BMI}$ are defined relative to $\mathrm{WHO}$ growth standards and the Tsiname reference population. A total of 100 simulations of the BAKA population was conducted

\begin{tabular}{|c|c|c|c|c|c|}
\hline & \multirow[t]{2}{*}{ Definition } & \multicolumn{2}{|c|}{ WHO growth standard } & \multicolumn{2}{|c|}{ Tsiname reference } \\
\hline & & $\begin{array}{l}\text { Observed } \\
{[\%]}\end{array}$ & $\begin{array}{l}\text { Mean }_{\text {simulations }} \pm \mathrm{SD}, \\
\text { Range [\%] }\end{array}$ & $\begin{array}{l}\text { Observed } \\
{[\%]}\end{array}$ & $\begin{array}{l}\mathrm{Mean}_{\text {simulations }} \pm \mathrm{SD}, \\
\text { range }[\%]\end{array}$ \\
\hline Stunting & $\mathrm{z}_{\mathrm{HA}} \leq-2$ & 57.8 & $57.3 \pm 0.06,55.9-58.6$ & 10.9 & $11.4 \pm 0.005,10.3-12.6$ \\
\hline Underweight & $\mathrm{z}_{\mathrm{WA}} \leq-2$ & 25.5 & $25.5 \pm 0.005,24.4-26.6$ & 10.2 & $10.6 \pm 0.004,9.6-11.7$ \\
\hline Wasting & $\mathrm{z}_{\mathrm{WH}} \leq-2$ & 3.4 & - & 6.7 & - \\
\hline Overweight & $\mathrm{z}_{\mathrm{WH}} \geq 2$ & 4.6 & - & 4.6 & - \\
\hline Low BMI & $\mathrm{z}_{\mathrm{BA}} \leq-2$ & 4.3 & $4.3 \pm 0.001,4.0-4.7$ & 7.0 & $7.1 \pm 0.001,6.9-7.4$ \\
\hline
\end{tabular}

First, each individual was assigned a random birth date within the respective birth cohort, second, z-scores were calculated using the simulated birth dates, and, third, population malnutrition was then calculated 
Table 5 Sample sizes, mean z-scores and percent of $\mathrm{z}$-scores $\leq-2$ relative to WHO standards for Baka from this study and for the Amazonian Tsimane (Tsi) people (Blackwell et al. 2017)

\begin{tabular}{|c|c|c|c|c|c|c|c|c|c|}
\hline parameter & Age (years) & $\begin{array}{l}\text { Baka } \\
\mathrm{n}\end{array}$ & $\begin{array}{l}\text { Baka } \\
\text { mean } \pm \mathrm{SD}^{\mathrm{a}} \mathrm{z}\end{array}$ & $\begin{array}{l}\text { girls } \\
\text { Baka } \\
\% \mathrm{z} \leq-2\end{array}$ & $\begin{array}{l}\text { Tsi } \\
\% \mathrm{z} \leq-2\end{array}$ & $\begin{array}{l}\text { Baka } \\
\mathrm{n}\end{array}$ & $\begin{array}{l}\text { Baka } \\
\text { mean } \pm \mathrm{SD}^{\mathrm{a}} \mathrm{z}\end{array}$ & $\begin{array}{l}\text { boys } \\
\text { Baka } \\
\% \mathrm{z} \leq-2\end{array}$ & $\begin{array}{l}\text { Tsi } \\
\% \mathrm{z} \leq-2\end{array}$ \\
\hline \multirow[t]{2}{*}{ Height-for- age (HA) } & $\geq 2,<5$ & 230 & $-2.5 \pm 0.2$ & 64.4 & 54.6 & 245 & $-2.9 \pm 0.3$ & 73.1 & 55.7 \\
\hline & $\geq 5,<10$ & 224 & $-1.7 \pm 0.5$ & 41.0 & 38.7 & 260 & $-2.1 \pm 0.3$ & 51.2 & 42.5 \\
\hline \multirow[t]{2}{*}{ Weight-for- age (WA) } & $\geq 2,<5$ & 230 & $-1.5 \pm 0.1$ & 30.9 & 14.2 & 245 & $-1.6 \pm 0.2$ & 37.1 & 14.1 \\
\hline & $\geq 5,<10$ & 224 & $-1.2 \pm 0.4$ & 18.3 & 12.0 & 260 & $-1.5 \pm 0.1$ & 29.2 & 13.6 \\
\hline \multirow[t]{2}{*}{ BMI-for- age (BA) } & $\geq 2,<5$ & 230 & $0.3 \pm 0.3$ & 4.8 & 2.2 & 245 & $0.6 \pm 0.2$ & 4.1 & 0.62 \\
\hline & $\geq 5,<10$ & 224 & $0 \pm 0.3$ & 1.8 & 0.6 & 260 & $-0.1 \pm 0.4$ & 5.8 & 0.36 \\
\hline \multirow[t]{2}{*}{ Weight-for- height (WH) } & $\geq 2,<5$ & 230 & $0.1 \pm 0.3$ & 5.7 & 2.4 & 245 & $0.2 \pm 0.1$ & 4.90 & 0.52 \\
\hline & $\geq 5,<10$ & 181 & $0.1 \pm 0.2$ & 1.7 & 1.4 & 223 & $0.3 \pm 0.2$ & 4.04 & 0.61 \\
\hline
\end{tabular}

As the respective table for Tsimane refers only to 2 to 10 year olds, we present here also only Baka children less than 10 years old

a : means \pm SD over yearly cohorts

explanation (Stinson 1990, 2012; Orr et al. 2001; Foster et al. 2005), the evidence for a genetic basis for the Pygmy phenotype is overwhelming.

Genome-wide DNA data indicate that the South African and the Central African clades of hunter-gatherers, who both split around 250,000-200,000 years ago from other populations, represent the oldest known branches of modern human genetic variation (Lipson et al. 2020). Notwithstanding genetic admixture with other populations, modern Pygmy people retain much of this unique genetic legacy (Lipson et al. 2020). Nuclear and mitochondrial data from different population genetic marker systems indicate that Central African hunter-gatherers and farmers diverged from each other $\sim 30,000-150,000$ years ago, whilst West- and East-Central African hunter-gatherer populations separated $\sim 25,000$ years ago (Patin et al. 2009; Verdu et al. 2009; Batini et al. 2011; Hsieh et al. 2016; Lopez et al. 2018). Thus, African compared to Amazonian hunter-gatherers have had much more time for the selection of genetic adaptations to a tropical rainforest environment to occur. A genome scan with SNP markers identified one genomic region and eight genes associated with hunter-gatherer/farmer status, and 24 genes associated with the height-related traits; many of these genes have putative functions for the Pygmy phenotype (Pemberton et al. 2018). Several lines of evidence support that these genetic foundations are the result of adaptation to the particular environment. First, the Pygmy phenotype evolved more than once independently from each other. Signals of positive selection of loci nearby genes involved in the Pygmy phenotype differ between Western and Eastern Central African Pygmy populations (Perry et al. 2014). This corresponds with different growth dynamics of Pygmy people from these locations (Rozzi et al. 2015). Second, several recent studies evidenced positive selection for loci linked to the Pygmy phenotype (Jarvis et al. 2012; Lachance et al. 2012; Migliano et al. 2013; Amorim et al. 2015; Hsieh et al. 2016).

\section{One Growth Standard for Size Fits all?}

We emphasize that using the WHO growth curves as references is ideal for comparing populations, identifying secular trends within populations and to characterize growth patterns in relation to environmental and health parameters. Applying WHO references greatly improves the comparison of data from different populations, such as in the case of the Tsimane and Shuar (Urlacher et al. 2016; Blackwell et al. 2017). Applying growth references that are rarely used elsewhere, as in the case of French growth standards applied to the Baka (Ramírez Rozzi et al. 2015), does not facilitate the comparison of results. Besides their use as references, WHO growth curves are also being vehemently defended as growth standards regardless of ethnicity with the explicit aim to gear health interventions and policies towards achieving these idealized growth standards (WHO Multicentre Growth Reference Study Group 2006; de Onis 2008; de Onis et al. 2012; Ong 2017). There is, of course, a logistic and economic imperative in applying the same child growth standards and to aim for the same model for optimal growth independently of ethnicity (de Onis 2008; de Onis et al. 2012). A number of studies have already argued that the WHO growth charts do not perfectly fit all combinations of ethnic/socioeconomic background and ongoing secular trends, and no reference population or growth standard can provide an optimal statistical fit (Ong 2017).

Whilst it cannot be excluded that small statures and high stunting rates of Amazonian populations are mainly a consequence of environmental and health-related factors rather than genetics (Walker et al. 2006; Urlacher et al. 2016; Blackwell 
et al. 2017), the genetic data and in particular the evidence for genetic adaptation to the environment of Pygmy populations highlight that the genetic foundation of growth variability must be considered alongside environmental factors for interpreting child growth. Future studies need to ascertain the relative impact of genetic versus environmental factors in Baka and other Pygmy populations.

Small indigenous populations are neither represented in the populations used to develop the UN growth standard nor are they adequately represented in research on children's growth. Where studies exist, they show that indigenous child growth patterns differ substantially from those of Western children including Amazonian populations, African pastoralists, African Pygmy populations, and populations from tropical Asia and Australia (Bailey 1991; Ulijaszek et al. 1995; Henneberg et al. 2001; Gray et al. 2004; Walker et al. 2006; Urlacher et al. 2016; Blackwell et al. 2017).

\section{Implications}

Our results strongly indicate that the WHO growth standard height-for-age is inadequate for the studied Baka Pygmy population and that the development of an adequate standard is required. Baka are a representative group of the Western Central African Pygmy populations, which are genetically differentiated from the Eastern Central African Pygmy populations and who have different growth dynamics (Perry et al. 2014; Ramírez Rozzi et al. 2015). Future work needs to evaluate these Eastern populations.

As neither our study nor the previous one on Baka, nor the studies on the Tsimane, demonstrate a deviation of the standards for weight-for-height and BMI-for-age, these should continue to be used. Our advice is to use only weight-forheight and BMI-for-age relative to the WHO standard as diagnostic tools. The height-for-age parameter related to a local reference is still useful to identify the most vulnerable children at risk for disease and malnutrition, whether $-2 \mathrm{z}$ or any other adequate percentage or quantile but only if it is carefully interpreted alongside other individual health data.

Without a proper standard or with a biased standard, the most-often applied and normally powerful parameter heightfor-age will leave the clinician without the background information needed to interpret these data (Ong 2017). Because stunting is used as a marker to identify malnutrition on a personal level and to quantify the prevalence of malnutrition on a population level, failure to distinguish between genetically determined short stature and nutrition-based linear growth failure renders stunting inadequate as a diagnostic tool. At this stage we neither know the growth potential under optimal nutritional conditions nor how much of the observed small stature is caused by malnutrition in Baka children. As a result, it is difficult to propose adequately targeted individual health care or clear national and international health policies for this ethnic group. At an individual level, the wrong application of the WHO size standards opens the door for misinterpretations by health practitioners and parents. Applying the size standard could stigmatize almost two-thirds of the population that they or their children are too small, representing abnormal growth, and as a result mistaken or unnecessary solutions such as supplementary feeding and hormone treatments prescribed. Applying only a local reference, which is not developed to function as a standard, bears the danger that undernutrition is normalizing poor growth as the socially accepted standard. At a population level the current data on stunting and wasting in Baka are insufficient to provide meaningful information for achieving the UN Sustainable Development Goals for these peoples, not to mention other Pygmy populations which are even more data deficient.

Considering that the central African region is under severe socioeconomic pressures and is affected by numerous politico-religious crises, armed conflicts, and population displacements, health care and sustainable development are often severely compromised. Malnutrition not only impacts stunting in Baka, albeit the degree remains unknown, but also the decline of adult BMI over age, which is in contrast to all non-Pygmy sympatric populations (Funk et al. 2020), thus contributing to the observed dramatically different life expectancy rate between Pygmy and neighboring Bantu populations (Anderson et al. 2016). There is therefore a need for more investments to improve the health of individuals and populations, as shown by the concerted efforts to provide optimal health care and reduce acute malnutrition in Central Africa (Ndzo and Jackson 2018). These laudable attempts could be disastrously undermined if misguided advice is given based on wrong growth standards.

Any ethnicity-based consideration for health care must be done with utmost concern for the highest ethical and moral standards, especially in ethnically diverse regions where ethnicity has played such a large role in human armed conflicts and persecutions. The resistance to acknowledge ethnicity as a parameter for developing ethnicity-based growth standards and promoting a universal standard might reflect concerns about ethical principles in health care and the nevermentioned 'elephant in the room' - racism. Alleged genetic differences between human groups has been severely misused in the past and the consideration of such differences has provoked strong ethical concerns (Winegard et al. 2017). However, the WHO size standards produce so vastly exaggerated stunting values and may also bias other estimates of malnutrition that their application in Pygmy populations is not only obsolete but might be counterproductive. If we are not to fail these already disadvantaged groups of people (Ohenjo et al. 2006; Anderson et al. 2016; Akombi et al. 2017), we need to act now to provide baseline data to evaluate children's growth based on standards specific to their ethnic background. 
Acknowledgements We thank Maria Rebollo for allowing us to use data gathered during the 2010 campaign. Julienne Meyina and Mirabelle Assampelle, nurses within the Zerca y Lejos health programme, assisted in the campaigns. We appreciate the advice given by Aaron D. Blackwell to implement the R package 'gamlss'. We thank the reviewers for proactive and helpful comments. JEF was partly funded by the US Agency for International Development as part of the Bushmeat Research Initiative of the CGIAR research program on Forests, Trees and Agroforestry. AI acknowledges support from the United States Agency for International Development's Forestry and Biodiversity Office (USAID-FAB) and the CGIAR's research program on Forests, Trees and Agroforestry (FTA).

Financial Support Funding was provided by UK Government's Darwin Initiative (Project no. 24029).

Authorship JEF, BPG, ABZ, NAP and GRB were responsible for the study design. SMF undertook the data analysis, data interpretation, figure construction, and manuscript writing. JEF, AI and BPG contributed to data interpretation, and manuscript writing. AI contributed to the data interpretation, and manuscript writing. Data in the field were gathered by BPG, NAP, MAA, YHS, RP, GRB, MA, EAM, RO, BAZ, AMC, CGS, CRLG, FLRS, HA, and IAR. All authors approved the final version to be published.

\section{Compliance with Ethical Standards}

Conflict of Interest The authors declare they have no competing interests.

Ethical Standards Disclosure This study was conducted according to the guidelines laid down in the Declaration of Helsinki and all procedures involving research study participants were approved by the Ministry of Territorial Administration and Decentralization (Arrete No. 00034) awarded to $\mathrm{ZyL}$ to perform health and development work within the Djoum-Mintom region. Verbal informed consent was obtained from all subjects. Verbal consent was witnessed and formally recorded. We followed the Guidelines for Applying Free, Prior and Informed Consent (Buppert \& McKeehan 2013). To maintain confidentiality, all participant names were dissociated from all datasheets prior to data analysis.

Disclosure Buppert T \& McKeehan A (2013) Guidelines for Applying Free, Prior and Informed Consent: A Manual for Conservation International. Arlington, VA: Conservation International.

Open Access This article is licensed under a Creative Commons Attribution 4.0 International License, which permits use, sharing, adaptation, distribution and reproduction in any medium or format, as long as you give appropriate credit to the original author(s) and the source, provide a link to the Creative Commons licence, and indicate if changes were made. The images or other third party material in this article are included in the article's Creative Commons licence, unless indicated otherwise in a credit line to the material. If material is not included in the article's Creative Commons licence and your intended use is not permitted by statutory regulation or exceeds the permitted use, you will need to obtain permission directly from the copyright holder. To view a copy of this licence, visit http://creativecommons.org/licenses/by/4.0/.

\section{References}

Akombi BJ, Agho KE, Merom D, et al (2017) Child malnutrition in subSaharan Africa: A meta-analysis of demographic and health surveys
(2006-2016). PLoS One 12:e0177338. https://doi.org/10.1371/ journal.pone. 0177338

Amorim CEG, Daub JT, Salzano FM, et al (2015) Detection of Convergent Genome-Wide Signals of Adaptation to Tropical Forests in Humans. PLoS One 10:e0121557. https://doi.org/10. 1371/journal.pone.0121557

Anderson I, Robson B, Connolly M, et al (2016) Indigenous and tribal peoples' health (The Lancet-Lowitja Institute Global Collaboration): a population study. The Lancet 388:131-157. https://doi.org/10.1016/S0140-6736(16)00345-7

Bailey RC (1991) The comparative growth of Efe pygmies and African farmers from birth to age 5 years. Annals of Human Biology 18: 113-120. https://doi.org/10.1080/03014469100001452

Batini C, Lopes J, Behar DM, et al (2011) Insights into the Demographic History of African Pygmies from Complete Mitochondrial Genomes. Molecular Biology and Evolution 28:1099-1110. https://doi.org/10.1093/molbev/msq294

Becker NSA, Verdu P, Froment A, et al (2011) Indirect evidence for the genetic determination of short stature in African Pygmies. American Journal of Physical Anthropology 145:390-401. https://doi.org/10. 1002/ajpa.21512

Blackwell AD, Urlacher SS, Beheim B, et al (2017) Growth references for Tsimane forager-horticulturalists of the Bolivian Amazon. American Journal of Physical Anthropology 162:441-461. https:// doi.org/10.1002/ajpa.23128

Bloem, M. (2007). The 2006 WHO child growth standards. 334:705706. https://doi.org/10.1136/bmj.39155.658843.BE

Darwin Initiative. (n.d.). Enabling Baka attain food security, improved health and sustain biodiversity. https://www.darwininitiative.org.uk/ project $/ 24029 /$. Accessed 25 Oct 2018

de Onis M (2008) Child Growth and Development. In: Semba RD, Bloem MW (eds) Nutrition and health in developing countries, 2nd ed. Humana Press, Totowa, pp 133-138

de Onis M, Onyango AW, Borghi E, et al (2007) Development of a WHO growth reference for school-aged children and adolescents. Bulletin of the World Health Organization 85:660-667

de Onis M, Onyango A, Borghi E, et al (2012) Worldwide implementation of the WHO Child Growth Standards. Public Health Nutrition 15:1603-1610. https://doi.org/10.1017/S136898001200105X

Diekmann Y, Smith D, Gerbault P, et al (2017) Accurate age estimation in small-scale societies. Proceedings of the National Academy of Sciences of the United States of America 114:8205-8210. https:// doi.org/10.1073/pnas.1619583114

Dinerstein E, Olson D, Joshi A, et al (2017) An Ecoregion-Based Approach to Protecting Half the Terrestrial Realm. BioScience 67: 534-545. https://doi.org/10.1093/biosci/bix014

Foster Z, Byron E, Reyes-García V, et al (2005) Physical growth and nutritional status of Tsimane' Amerindian children of lowland Bolivia: Growth of Tsimane' Children. American Journal of Physical Anthropology 126:343-351. https://doi.org/10.1002/ajpa. 20098

Froment A (1993) Adaptation biologique et variation dans l'espèce humaine : le cas des Pygmées d'Afrique. Bulletins et Mémoires de la Société d'anthropologie de Paris 5:417-448. https://doi.org/10. 3406/bmsap.1993.2371

Funk, S. M., Palomo Guerra, B., de Mena Martínez, N. et al. (2020). Divergent trajectories of BMI over age for adult Baka Pygmy people and their sympatric non-Pygmy populations. Human Ecology. https://doi.org/10.1007/s10745-020-00151-7

Gavrilov, I., Pusev, R. (2015). Package 'normtest'.

Gray SJ, Wiebusch B, Akol HA (2004) Cross-sectional growth of pastoralist Karimojong and Turkana children. American Journal of Physical Anthropology 125:193-202. https://doi.org/10.1002/ajpa. 10377

Gurven M, Kaplan H, Supa AZ (2007) Mortality experience of Tsimane Amerindians of Bolivia: Regional variation and temporal trends. 
American Journal of Human Biology 19:376-398. https://doi.org/ 10.1002/ajhb.20600

Heaton TB, Crookston B, Pierce H, Amoateng AY (2016) Social inequality and children's health in Africa: a cross sectional study. International Journal for Equity in Health 15: 92. https://doi.org/ 10.1186/s12939-016-0372-2

Henneberg M, Schilitz A, Lambert KM (2001) Assessment of the growth of children and physical status of adults in two Aboriginal communities in South Australia. American Journal of Human Biology 13: 603-611. https://doi.org/10.1002/ajhb.1098

Hewlett BS (ed) (2014) Hunter-gatherers of the Congo Basin: cultures, histories and biology of African Pygmies. Transaction Publishers, New Brunswick

Hill, K., Hurtado, A. M. (2017). Aché Life History: The Ecology and Demography of a Foraging People. Taylor \& Francis

Hsieh P, Veeramah KR, Lachance J, et al (2016) Whole-genome sequence analyses of Western Central African Pygmy huntergatherers reveal a complex demographic history and identify candidate genes under positive natural selection. Genome Research 26: 279-290. https://doi.org/10.1101/gr.192971.115

Indrayan A (2014) Demystifying LMS and BCPE methods of centile estimation for growth and other health parameters. Indian Pediatrics 51:37-43. https://doi.org/10.1007/s13312-014-0310-6

Jarvis JP, Scheinfeldt LB, Soi S, et al (2012) Patterns of Ancestry, Signatures of Natural Selection, and Genetic Association with Stature in Western African Pygmies. PLoS Genetics 8:e1002641. https://doi.org/10.1371/journal.pgen.1002641

Jelenkovic A, Sund R, Hur Y-M, et al (2016) Genetic and environmental influences on height from infancy to early adulthood: An individualbased pooled analysis of 45 twin cohorts. Scientific Reports 6: 28496. https://doi.org/10.1038/srep28496

Lachance J, Vernot B, Elbers CC, et al (2012) Evolutionary History and Adaptation from High-Coverage Whole-Genome Sequences of Diverse African Hunter-Gatherers. Cell 150:457-469. https://doi. org/10.1016/j.cell.2012.07.009

Lipson M, Ribot I, Mallick S, et al (2020) Ancient West African foragers in the context of African population history. Nature https://doi.org/ 10.1038/s41586-020-1929-1

Lohman T, Roche A, Martorell R (1988) Anthropometric Standardization Reference Manual. Human Kinetics Books, Champaign

Lopez M, Kousathanas A, Quach H, et al (2018) The demographic history and mutational load of African hunter-gatherers and farmers. Nature Ecology and Evolution 2:721-730. https://doi.org/10.1038/ s41559-018-0496-4

Martin M, Blackwell A, Kaplan H, Gurven M (2019) Differences in Tsimane children's growth outcomes and associated determinants as estimated by WHO standards vs. within-population references. PLoS One 14:e0214965. https://doi.org/10.1371/journal.pone. 0214965

Migliano AB, Romero IG, Metspalu M, et al (2013) Evolution of the Pygmy Phenotype: Evidence of Positive Selection from Genomewide Scans in African, Asian, and Melanesian Pygmies. Human Biology 85:Article 12

Nagahori C, Kinjo Y, Tchuani JP, Yamauchi T (2017) Malnutrition among vaccinated children aged 0-5 years in Batouri, Republic of Cameroon. Journal of General and Family Medicine 18:365-371. https://doi.org/10.1002/jgf2.104

Natale V, Rajagopalan A (2014) Worldwide variation in human growth and the World Health Organization growth standards: a systematic review. BMJ Open 4:e003735. https://doi.org/10.1136/bmjopen2013-003735

NCD Risk Factor Collaboration (NCD-RisC) (2016) A century of trends in adult human height. eLife 5: e13410. https://doi.org/10.7554/ eLife. 13410

Ndzo JA, Jackson A (2018) Outcomes of children aged 6-59 months with severe acute malnutrition at the GADO Outpatient Therapeutic
Center in Cameroon. BMC Research Notes 11: 68. https://doi.org/ 10.1186/s13104-018-3177-0

Ohenjo N, Willis R, Jackson D, et al (2006) Health of Indigenous people in Africa. The Lancet 367:1937-1946. https://doi.org/10.1016/ S0140-6736(06)68849-1

Olivero J, Fa JE, Farfán MA, et al (2016) Distribution and Numbers of Pygmies in Central African Forests. PLoS One 11:e0144499. https://doi.org/10.1371/journal.pone.0144499

Ong KK (2017) WHO Growth Standards - Suitable for Everyone? Yes. Paediatric and Perinatal Epidemiology 31:463-464. https://doi.org/ 10.1111/ppe. 12396

Orr CM, Dufour DL, Patton JQ (2001) A comparison of anthropometric indices of nutritional status in Tukanoan and Achuar Amerindians. American Journal of Human Biology 13:301-309. https://doi.org/ 10.1002/ajhb.1053

Park AL, Tu K, Ray JG, the Canadian Curves Consortium (2017) Differences in growth of Canadian children compared to the WHO 2006 Child Growth Standards. Paediatric and Perinatal Epidemiology 31:452-462. https://doi.org/10.1111/ppe.12377

Patin E, Laval G, Barreiro LB, et al (2009) Inferring the Demographic History of African Farmers and Pygmy Hunter-Gatherers Using a Multilocus Resequencing Data Set. PLoS Genetics 5:e1000448. https://doi.org/10.1371/journal.pgen.1000448

Pemberton TJ, Verdu P, Becker NS, et al (2018) A genome scan for genes underlying adult body size differences between Central African hunter-gatherers and farmers. Human Genetics 137:487-509. https://doi.org/10.1007/s00439-018-1902-3

Perry GH, Dominy NJ (2009) Evolution of the human pygmy phenotype. Trends in Ecology \& Evolution 24:218-225. https://doi.org/10. 1016/j.tree.2008.11.008

Perry GH, Verdu P (2017) Genomic perspectives on the history and evolutionary ecology of tropical rainforest occupation by humans. Quaternary International 448:150-157. https://doi.org/10.1016/j. quaint.2016.04.038

Perry GH, Foll M, Grenier J-C, et al (2014) Adaptive, convergent origins of the pygmy phenotype in African rainforest hunter-gatherers. Proceedings of the National Academy of Sciences 111:E3596E3603. https://doi.org/10.1073/pnas.1402875111

Prendergast AJ, Humphrey JH (2014) The stunting syndrome in developing countries. Paediatrics and International Child Health 34:250 265. https://doi.org/10.1179/2046905514Y.0000000158

Pridmore P, Carr-Hill R (2011) Tackling the drivers of child undernutrition in developing countries: what works and how should interventions be designed? Public Health Nutrition 14:688-693. https://doi. org/10.1017/S1368980010001795

R Foundation for Statistical Computing (2016) R. Version 3.3.1 GUI 1.68 Mavericks buildURL https://www.r-project.org

Ramírez Rozzi FV, Koudou Y, Froment A, et al (2015) Growth pattern from birth to adulthood in African pygmies of known age. Nature Communications 6: 7672. https://doi.org/10.1038/ncomms8672

Rigby RA, Stasinopoulos DM (2005) Generalized additive models for location, scale and shape. Journal of the Royal Statistical Society: Series C: Applied Statistics 54:507-554

Robinson MR, Hemani G, Medina-Gomez C, et al (2015) Population genetic differentiation of height and body mass index across Europe. Nature Genetics 47:1357-1362. https://doi.org/10.1038/ ng.3401

Rozzi FVR, Koudou Y, Froment A, et al (2015) Growth pattern from birth to adulthood in African pygmies of known age. Nature Communications 6: 7672. https://doi.org/10.1038/ncomms8672

Schell LM, Magnus PD (2007) Is there an elephant in the room? Addressing rival approaches to the interpretation of growth perturbations and small size. American Journal of Human Biology 19: 606-614. https://doi.org/10.1002/ajhb.20669

Sempé, P., Sempé, M. (1971). Croissance et maturation osseuse: Analyse auxologique et radiologique... Laboratiore Théraplix 
Stasinopoulos DM, Rigby RA (2007) Generalized additive models for location scale and shape (GAMLSS) in R. Journal of Statistical Software 23:1-46

Stinson S (1990) Variation in body size and shape among South American Indians. American Journal of Human Biology 2:37-51. https://doi.org/10.1002/ajhb.1310020105

Stinson S (2012) Growth Variation: Biological and Cultural Factors. In: Stinson S, Bogin B, O'Rourke D (eds) Human Biology. John Wiley \& Sons, Inc., Hoboken, pp 587-635

The Lancet (2016) Indigenous health: a worldwide focus. The Lancet 388:104. https://doi.org/10.1016/S0140-6736(16)31020-0

Ulijaszek, S. J., Ulijaszek, S. J., J US, Mascie-Taylor, C. G. N. (1995). Human Energetics in Biological Anthropology. Cambridge University Press

UNICEF, WHO, World Bank (2020) Levels and trends in child malnutrition. Key findings of the 2020 edition of the Joint Child Malnutrition Estimates. WHO, Geneva

Urlacher SS, Blackwell AD, Liebert MA, et al (2016) Physical growth of the shuar: Height, Weight, and BMI references for an indigenous amazonian population: Shuar physical growth. American Journal of Human Biology 28:16-30. https://doi.org/10.1002/ajhb.22747

Verdu P, Austerlitz F, Estoup A, et al (2009) Origins and Genetic Diversity of Pygmy Hunter-Gatherers from Western Central
Africa. Current Biology 19:312-318. https://doi.org/10.1016/j.cub. 2008.12.049

Walker R, Gurven M, Hill K, et al (2006) Growth rates and life histories in twenty-two small-scale societies. American Journal of Human Biology 18:295-311. https://doi.org/10.1002/ajhb.20510

WHO. (2018). Global Database on Child Growth and Malnutrition. In: World Health Organization. http://www.who.int/nutgrowthdb/ about/en/. Accessed 5 Jul 2018

WHO Multicentre Growth Reference Study Group. (2006). WHO Child Growth Standards based on length/height, weight and age: WHO Child Growth Standards. Acta Paediatrica. Supplement 145:76-85. https://doi.org/10.1111/j.1651-2227.2006.tb02378.x

Winegard B, Winegard B, Boutwell B (2017) Human Biological and Psychological Diversity. Evolutionary Psychological Science 3: 159-180. https://doi.org/10.1007/s40806-016-0081-5

World Health Organization. (1995). Physical status: The use of and interpretation of anthropometry, Report of a WHO Expert Committee. World Health Organization, Geneva

Zerca y Lejos. (2018). http://zercaylejos.org. Accessed 25 Oct 2018

Publisher's Note Springer Nature remains neutral with regard to jurisdictional claims in published maps and institutional affiliations. 